\title{
TOWARDS A THEORETICAL APPROACH TO THE UNDERSTANDING OF LANguAge IdeOLOgIES IN POST-MEIJI JAPAN
}

\author{
Luka CULIBERG \\ University of Ljubljana, Faculty of Arts, Department of Asian and African Studies \\ lukaculiberg@hotmail.com
}

\begin{abstract}
The paper aims to examine specific conditions that have generated the understanding of language in post-Meiji Japan and propose a theoretical approach to the question of why a specific view on language, or to use a more precise concept - a language ideology - was, and still is, inevitable within a specific ideological horizon, the horizon of nationalism. In order to do so, it first gives an overview of the linguistic situation in post-Meiji Japan with all its competing and opposing views, followed by an outline of the up to date research, its breakthroughs, its problems and its dead ends. Finally it proposes the orthodox method of historical materialism as possibly the only methodological approach hoping to grasp all these interconnected social problems in their totality.
\end{abstract}

\section{Keywords}

Japan, language, nation, ideology, theory, historical materialism

\section{Izvleček}

Članek poskuša raziskati pogoje, ki so pripeljali do posebnega pogleda na jezik na Japonskem od Obdobja Meiji naprej, in predlagati teoretski pristop k vprašanju, zakaj je določen pogled na jezik, ali natančneje - jezikovna ideologija, nujna v določenem ideološkem horizontu horizontu nacionalizma. Članek prinaša najprej pregled nad jezikovnim stanjem Obdobja Meiji in po njem z vsemi tekmujočimi in nasprotujočimi si pogledi, čemur sledi oris dosedanjih raziskav, njihovih prebojev, težav in slepih poti. Na koncu članek predlaga ortodoksno metodo historičnega materializma kot edini metodološki pristop, ki lahko upa, da bo vse te medsebojno prepletene družbene probleme lahko zajel v njihovi celoti.

\section{Ključne besede}

Japonska, jezik, narod, ideologija, teorija, historični materializem

日本語は日本民族のことばにほかならない (Kamei, Ōtō \& Yamada, 2006, p. 5).

Japanese language is nothing else but the language of the Japanese people. 
In October 2010 a Croatian nationalistic organisation called Hrvatsko kulturno vijeće (Croatian Cultural Council) ${ }^{1}$ filed charges against those responsible within the Ministry of Culture of the Republic of Croatia for co-financing the publication of the book by Croatian linguist Snježana Kordić titled Jezik $i$ nacionalizam (Language and Nationalism). Charges were pressed on the grounds that the book Language and Nationalism is directed against Croatian culture, Croatian cultural identity and the Croatian language, and therefore should not be co-financed from the state budget (Hitrec). ${ }^{2}$

This controversial book engages in the polemic with Croatian linguists by arguing about the Croatian language from the established linguistic premise that the so-called Croatian, Serbian, Bosnian and Montenegrin languages do not by any definition constitute different or separate languages but are merely variants of one polycentric standard language known in linguistics as Serbo-Croatian (or Croato-Serbian), and that claims by Croatian linguists to the contrary are not grounded upon any kind of scientific linguistic arguments but are rather the result of purely political and ideological motives (Kordić, 2010).

This particular polemic and its subsequent events are especially interesting since they clearly demonstrate that such sentiments towards language, having been around for some time, have not yet lost their momentum. For example, approximately one hundred years ago in a completely different part of the world a similar group of people came together in order to protect the integrity of its national language and fend off dangerous attempts at undermining the nation's substance and its tradition. In 1905 a group of conservatives calling themselves Kokugokai (国語会 National Language Association), led by Privy Councillor Higashikuze Michitomi, announced their conviction that the fortunes of the language were closely linked to those of the nation (Gottlieb, 1995, p. 67), and therefore when one is compromised the other suffers as well. This and another group called Kokugo Yōgokai (国語国擁護会 Association for Defence of the National Language) were established primarily as a response to the language planning activities and the proposed language reforms by the formal governmental body established within the Ministry of Education with the aim of carrying out thorough investigation of the state of the language in Japan at the beginning of the 20th century.

The present paper intends to examine specific conditions that have generated the understanding of language in post-Meiji Japan and show why a specific view on language, or to use a more precise concept - a language ideology - was, and still is, inevitable within a specific ideological horizon, the horizon of nationalism.

\footnotetext{
${ }^{1}$ Article 1 of the Council's program states: "Croatian Cultural Council (HKV) through its activities affects the whole of Croatian reality, with the aim of affirming the values that are woven into Croatian tradition and constitute the source of Croatian cultural and national identity." (Program Hrvatskoga kulturnog vijeća, para. 1.)

${ }^{2}$ State Attorney's Office in Zagreb dropped the charges in January 2011.
} 
The problem this paper wishes to address is the change in language ideology as a consequence of the change in material conditions of the Japanese society after the transition from the bakuhan taisei type of feudal system of Tokugawa Japan to the capitalist market economy of the Meiji period. The transition from feudal society to liberal democracy was of course not instantaneous, but the material conditions of economic liberalism brought about ideological shifts that eventually demanded the institution of liberal democracy. ${ }^{3}$ From the Meiji Restoration onwards almost every two decades Japan's politics had experienced radical change, and it was not until the end of the Second World War that the liberal democratic system was established. Unlike the revolutions in the United States or France, the Meiji Restoration was not a modern type revolution, since it was the lower-class samurai who initiated the political reform; they were not exactly supporters of modern democracy and were hardly willing to relinquish power easily once they took hold of it (Tanaka, 1994, p. 57). However, once the course of capitalist economy, industrialisation and modernisation of Japan following the Western model had been chosen, it was only a matter of time before the liberal democracy was to have its way as well. One evidence to that is the emergence of liberal ideologues already early in the Meiji period, such as Fukuzawa Yukichi, whose powerful voices and opinions even the Meiji government had no choice but to listen to (Tanaka, 1994, p. 58).

To return to the question of language, we have to examine the causes that led to the situation in which the need for language reform and planning suddenly appeared. In many respects this seems obvious and appears to have already been answered numerous times. The transformation of Japanese society into a single nation demanded the unification of language, which could only have been achieved through a universal school system and the spread of literacy. This, in turn, demanded the orthographic reform and standardisation of written style that should correspond to the colloquial style, i.e. writing should be considered only as a means to record spoken language.

However not everyone shared these views. In fact, language planning was contested and opposed on practically every possible aspect, with disagreements and disputes emerging between supporters of the colloquial written style and those who were in favour of preserving the classical way of writing, those who supported limiting or abolishing Chinese characters and those who wanted to preserve them, those who were in favour of adopting the Japanese kana syllabary and those who opted for the introduction of the Roman alphabet, etc.

The reason for this plurality of attitudes toward language in the newly emerged Japanese society of the Meiji Period requires a complex explanation that has been attempted in more detail elsewhere (Culiberg, 2007), but suffice it to say that the main characteristic of nationally structured individualistic societies is the fact that their members ideologically perceive themselves as belonging to the nation, not indirectly

\footnotetext{
${ }^{3}$ For an outline of this process that has passed through many stages since the Meiji restoration (1868), see Tanaka (1994).
} 
through any kind of social status, position or rank within the society or some other type of institutional affiliation, but directly in their abstraction as abstract individuals. ${ }^{4}$ This ideological perception understands affiliation to the nation as being unconditional, innate and quasi-natural and thus provides the neutral ground which connects and totalises the ideological plurality and produces the effect of "social totality", i.e. reproduces society as a unified, homogenous group (Močnik, 1999, p. 93).

The adoption of a Western style capitalist market economy necessitated the abolition of the feudal structure of society and a redefinition of Japan as a modern type of nation-state composed of a unified and homogeneous group of Japanese nationals. As has been shown by Hobsbawm and others (2007), the process of nation-building involved many complex adaptations and reinterpretations of history, traditions, and of course - language. However, defining language as just another case of invented tradition requires a more detailed explanation concerning language ideologies. This will be attempted on the case of Japan from the Meiji Period onwards.

Official language planning in Japan began only in 1900, when it was first sanctioned at government level by appointing a team of experts to research the problem of national language or kokugo (国語). This led to the establishment of the first governmental body within the Ministry of Education, called the Kokugo chōsa iinkai (国語調査委員会 The National Language Research Council) in 1902 (Yasuda, 2006, p. 62). The policy of this council was that of the so-called reformists, who were concerned with issues such as establishing a written colloquial style, limiting or abolishing Chinese characters and reforming the historical kana usage (rekishiteki kanazukai) with phonetic kana usage (hyōonshiki kanazukai) or replacing them altogether with the Roman alphabet.

Upon its establishment in 1902 Kokugo chōsa iinkai proposed four main tasks to be approached and solved as the committee's primary goals. These were (Yasuda, 2006, p. 63):

1. Adopting the phonetic script; investigating the relative merits of kana and the Roman alphabet.

2. Adopting a colloquial style in writing; conducting research concerning the matter.

3. Conducting research into the phonetic structure of national language (kokugo).

4. Surveying the dialects and settling upon a standard language. ${ }^{5}$

\footnotetext{
${ }^{4}$ Contrary to the social order in Tokugawa Japan, based on the four class system known as shinōkōshō (士 農工商) of samurai, peasants, artisans and merchants with the addition of Buddhist and Shintō priests, court nobles and outcasts, each member of the society belonging to his or her own well-defined place in the social structure, Meiji Japan became a society composed of abstract individuals free of any kind of status connection and directly linked to the institution of nation as Japanese nationals.

5 一 文字八音韻文字（「フオノグラム」） ヨ採用スルコト、シ仮名羅馬字等ノ得失习調査ス ルコト

二 文章八言文一致体ヨ採用スルコト、シ是ニ関スル調査ヨ為スコト
} 
These four tasks clearly reveal the language policy that was adopted by linguists as well as the government at the beginning of the 20th century. There was the urgent question of settling upon and spreading the standard language across the archipelago as well as reforming the written language and bringing it in line with the spoken one; and finally, there was the question of abolishing altogether the burdensome Chinese characters and replacing them with one kind or another of phonetic script. This last point is especially interesting since this was the only instance when the Japanese government actually endorsed such policy that was of course immediately contested by the more conservative opponents. The final outcome settled upon after World War II limits the kanji (漢字) in official usage to approximately two thousand characters.

The language policy proposed by the National Language Research Council was primarily an attempt to put into practice the ideas propagated by linguist Ueda Kazutoshi, spiritus agens of the reform movement, who had returned to Japan a few years before the establishment of the Council after having studied linguistics in Europe. The idea behind (1) in connection to (2) - namely abolishing kanji and adopting a colloquial style of writing - was thus an attempt to break away from the kanbun kundokutai (漢文訓読体), a style of written language which was at the centre of Japanese writing at the time. It was primarily influenced by Ueda's training in modern European linguistics giving priority to the spoken over the written language (Yasuda, 2006, pp. 63-64).

Japan had officially declared its modern nationhood through the promulgation of the Meiji Constitution in 1889. A few years later, in 1894, the same year Japan had entered the war with China, Ueda Kazutoshi, who had been studying linguistics in Europe and was particularly inspired by the school of Junggrammatiker (Young Grammarians), returned to Japan and was appointed professor of philology at Tokyo Imperial University. It was in this heavily charged nationalistic atmosphere that he gave his famous lecture upon returning home, titled Kokugo to kokka to (国語と国家 $\varepsilon$ The national language and the state). In his lecture he explicitly stressed the need for "love for the Muttersprache", and passionately argued for the unity of national language, connecting it to the unity of nation, by arguing about the deep intrinsic relationship between language and its people and proclaiming the Japanese language as the spiritual blood of the Japanese people (Ueda, 1968, p. 110).

Influenced by Western scholarship, Ueda endeavoured to establish a standardised national language or kokugo ${ }^{6}$ and was passionately promoting the national language

\section{三 国語ノ音韻組織习調査スルコト \\ 四 方言习調査シテ標準語ヨ選定スルコト}

${ }^{6}$ Kokugo (国語), while at first a general term denoting any national language had since become synonymous with the Japanese language and has been used to designate Japanese as a school subject and a research object of Japanese linguistics (国語学 kokugogaku). When this language is being taught to nonJapanese speakers as a foreign language, however, it is referred to as nihongo or Japanese language. This distinction between $u s$ and them had been under debate for a long time, and recently small departures from this strict division have occurred, for instance when the Society of Japanese Linguistics voted to change its name from Kokugo Gakkai to Nihongo Gakkai in 2004, or when in a 2002 survey seventy-four universities 
studies or kokugogaku. He began his career with harsh criticism of the old-school scholars of Japanese classics, associated mostly with the national studies or kokugaku tradition of the Keichū (1640-1701), Kamo no Mabuchi (1697-1769) and Motoori Norinaga (1730-1801) line (Lee, 1996, p. 97). Ueda's view that language can be explained only by means of scientific linguistics and not by means of traditional kokugaku was similar to the view held by nineteenth-century European linguists who were critical of classical philology and were thus shifting the attention from written to spoken language while also maintaining that linguistic change is governed by rational laws and not by human intentions (Lee, 1996, p. 99). Ueda had been initiated into the world of European linguistics by Basil Hall Chamberlain who was at the time a professor of Japanese at Tokyo Imperial University where Ueda graduated (Yasuda, 2006, p. 46). From 1890 to 1894 he was studying in Europe, mostly in Germany and France, where he was further influenced by the mainstream linguistic school at the time - the Neogrammarians, that was especially strong in Leipzig, one of the places where Ueda spent most of his time abroad (Lee, 1996, p. 106). During his stay in Europe, however, Ueda was influenced not only by the academic circles of Junggrammatiker but also by the more public proponents of language ideology like the Allgemeine Deutsche Sprachverein which held extreme views concerning the unity of nation and language and was involved in extensive language purification movements (Lee, 1996, p. 116). The success of such movements was further secured by the spreading of patriotic nationalism through the public after the Prussian victory over France and the unification of Germany, not unlike general sentiments that spread through Japan during the Sino-Japanese war or the language purification hysteria in Croatia in the 90's after the war with Serbia and the achievement of national independence.

But if Ueda's views on language, strongly influenced by the "scientific" approach of Neogrammarians and nested in the Herder-Humboldt-Grimm line of thought that connected the spirit of the nation to its language ${ }^{7}$, were as nationalistic as they get, what can we say then of his opponents like the National Language Association or the Association for the Defence of National Language that were established as a response to the language planning activities by the National Language Research Council of which Ueda Kazutoshi was the main engine?

As mentioned above, these associations firmly opposed and strongly criticised Ueda's linguistic policies because they believed that the fortunes of the language were closely linked to those of the nation, in other words, because they believed exactly the same thing. However, although a national institution operates as an inevitable framework for language ideologies, as we have argued above, it does not necessarily support or generate one single ideological interpretation. On the contrary, as an

were found to have changed the name of the department concerned with Japanese language to Nihongo gakka (Gottlieb, 2005, p. 16).

${ }^{7}$ As Grimm stated, the unification of Germany could not depend on politics, economy or religion, but on making the German language the symbol of national unity, because Germany can exist only as a "linguistic nation" (Sprachnation) (Lee, 1996, p. 113). 
ideological institution it necessarily generates conflicting views and paradoxes which, on the other hand, it is fully capable of supporting with its "neutral" position and thus creating a framework where concrete ideological interpretations retain the status of relativity while the national institution itself achieves the status of the absolute.

Let us examine briefly the ideological background upon which the opponents of Ueda's language reforms have formulated their views. Language questions in Japan had already been present at least throughout the Edo period, especially within the socalled nativist school or kokugaku with Motoori Norinaga as its pinnacle. In the wake of modern nationalism this tradition had been reinterpreted as a uniquely Japanese version of philological tradition and was appropriated as such. It was exactly this desire to create a Japanese nationalism that was on par with, but not derived from, that of Western nation-states that motivated the production of the new kokugaku (shinkokugaku) of the Meiji period (Burns, 2003. p. 225).

From the Meiji period onward neo-nativists such as Haga Yaichi (1867-1927) went through painstaking efforts to construct a narrative of the rise of national consciousness stretching back to antiquity but culminating in the philological practice of Motoori Norinaga, a narrative that paralleled but never intersected with those of Western nationalisms. Situated within this narrative, Norinaga's work became presciently scientific, academic and modern - but still distinctly Japanese (Burns, 2003, p. 225).

Just like Ueda Kazutoshi, Haga Yaichi too had studied for four years in Europe and upon returning to Japan in 1904 he delivered a lecture before an assembly of students at Kokugakuin University entitled Kokugaku to wa nanizo ya (国学とは何ぞ や What in fact is kokugaku?) (Haga, 1968). The main difference between his and Ueda's speech was that though they both firmly believed in the superiority of modern "scientific" research, unlike Ueda who had discovered this method in European scholarship and had introduced it to Japan, Haga put his efforts into showing that there already existed in Japan a tradition of scholarship identical to that of Europe but of course at the same time distinctively Japanese (Haga, 1968). He talked about the history of European philology and concluded that there was a method within kokugaku which was identical to European scientific method and he went on to reinterpret the kokugaku tradition in terms of philology, using the term bunkengaku (文献学) as a translation for philology and applying it to the tradition of kokugaku (Haga, 1968):

Among Western philologists there was a very great and daring man called August Böckh. In his work On the study of Antiquity ${ }^{8}$ he had laid down a definition concerning philology which, according to his belief, can be considered an illustrious science $^{9}$ in today's meaning of the word. I will follow and discuss his ideas later, but

\footnotetext{
${ }^{8}$ I presume that the title Kogaku kōyo (古学綱要) that Haga mentiones in his text refers to the speech by Böckh titled De antiquitatis studio published in Vol. 1. of his Gesammelte kleine Schriften (1858), where he discusses his theories concerning philology.

9 サイエンス即ち科学
} 
the fact is that Japanese kokugaku equals Japanese philology ${ }^{10}$. Japanese people have called it kokugaku and if Western philology, the kind Böckh had advocated, constitutes a scientific discipline, then Japanese kokugaku is nothing less than illustrious science as well (Haga, 1986, p. 230).

Whereas Ueda dismissed kokugaku as obsolete and unscientific in favour of modern Western science, Haga, on the other hand, endeavoured to inscribe the same "scientific" ideology into the kokugaku tradition itself. Both have argued from the same paradigmatic perspective but with completely opposite ideological interpretations. Ueda believed that Japanese language could be greatly improved by adopting a standard form of language and a colloquial style in writing and did not view this as tampering with tradition or destroying a respected cultural icon. Quite the contrary, for him to refine the national language meant treating it with respect (Gottlieb, 2005, p. 45).

This "clash of ideologies" was of course not limited to these two individuals but was rather systemic in its nature. Ueda's followers in the twentieth century such as Hoshina Kōichi or Hirai Masao who were advocating the so-called genbun'itchi movement - the unification of written and spoken language - and the introduction of the Roman alphabet, were strongly opposed by conservative traditionalists such as Yamada Yoshio or Tokieda Motoki who were in favour of preserving the historical usage of writing and traditional literary style. Tokieda even constructed his own grammatical theory, called language process theory (言語過程説 gengo katei setsu), in part also as a criticism of Saussure and his synchronic language theory.

The ideas of language "reformists" met with resistance not only from the more conservative linguists but also from the official government establishment. If the novel concept of nationalism became a platform for language ideologies as represented in Ueda's ideas about the formation of a new standard national language (kokugo), the same nationalistic ideology also brought about a different view on national language, one which saw any reform debate as a direct attack on national values, history and tradition. These "values", representing a distinct pattern of national unity around the Emperor, eventually received articulated form and official status within the concept of kokutai (国体) or "national polity". Forming one of the basic constructs within kokutai was kotodama (言霊) or "the spirit of the Japanese language", a term used to imply an inseparable connection existing between the unique Japanese language and the essence of the Japanese spirit (Gottlieb, 2005, p. 47).

Ever since the Meiji Restoration, language policies as well as general attitudes toward language in Japan were dominated by one or another form of language ideology. As early as 1866 Maejima Hisoka (1835-1919), who later sat together with Ueda Kazutoshi in the Kokugo chōsa iinkai, submitted to the shogun his Kanji onhaishi no gi (漢字御廃止之議 The argument for the abolition of kanji), a petition in which he already drew the connection between script and national power (Gottlieb,

\footnotetext{
${ }^{10}$ 日本の国学は日本の文献学である。日本のフイロロギーである。
} 
1995, p. 48). The idea that writing is only a representation of the spoken language gave birth to the movement in Meiji period called genbun'itchi or the unification of spoken and written language.

Concerning the questions of orthography, there were those, like the above mentioned liberal Fukuzawa Yukichi, who had advocated the rationalised and simplified form of the existent writing system and were in favour of limiting the number of kanji, those who had propagated the use of phonetic kana script, as well as those who were in favour of adopting the Roman alphabet. They were, in turn, opposed by those traditionalists who claimed that the written style of Japanese is not the spoken language, and that kanji and historical usage of kana were part of a long literary tradition. However, though the script reform debate had been going on ever since the beginning of the Meiji Period, it was not until the end of World War II and the Allied occupation of Japan that it was actually partly implemented by modernising kana spelling and limiting the number of kanji as well as introducing certain simplified forms. However, since the 1960s the reform had again taken the reverse course by softening the kanji limit requirements and slowly increasing their number. ${ }^{11}$

As for standardization of the spoken language, the situation was no better and in extreme cases it went as far as Mori Arinori's somewhat fatalistic suggestion early in the Meiji period to rather adopt English as the standard language in Japan, the idea that had probably still echoed in 1946 when in the sombre atmosphere of the post-war destruction the famous Japanese novelist Shiga Naoya made a similar statement in a published article proposing that Japan should adopt French as its national language (Kindaichi, 1988, p. 1).

The language reform movements have been studied extensively in Japan as Ueda (2008) notes, especially since Yamamoto Masahide (1907-1980) whose works on genbun'itchi movement, prominent until the 1970s, left a valuable imprint on the study of language reform (p. 131). His scholarship gave way to a new scholarly trend in the 1980s, as Karatani Kōjin and others, grounded in post-structuralist theories, argued that the genbun'itchi movement in fact produced a new écriture, based on phonocentrism. ${ }^{12}$ Ueda (2008) further notes that this perspective on the linguistic reform movements took off further as recent literary and linguistic scholars such as Lee Yeounsuk, Osa

\footnotetext{
${ }^{11}$ At the time, along with economic growth, Japan was experiencing a resurgence of conservatism which contributed to the increasing sense that post-war reforms had gone too far. As Gottlieb (1995) writes, soon after the release of the interim report of a special subcommittee of the LDP recommending a return to the old ways, the now-reorganised Council was instructed by the Education Minister in 1966 to re-examine the post-war cycle of reforms (p. 16). The character list was revised and expanded and kanji "restriction" was reformulated as mere "recommendation". The last kanji reform adding again more characters to the list has been introduced in 2010 .

${ }^{12}$ Karatani (1995) claims that phonocentrism was already present within the kokugaku of the eighteenth century and according to him the buds of nationalism appeared first and foremost in Japan in the movement to privilege phonetic writing within the Chinese character cultural sphere, a situation that was far from unique in Japan, since with respect to the forming of nations, the same problem has emerged all over the world and thus he believes a historical consideration of the case of Japan should look at the problem from a more universal perspective (pp. 5-6).
} 
Shizue, Komori Yōichi, and Yasuda Toshiaki have focused on nationalisation and deAsianisation of language and have been discussing linguistic reforms also from the standpoint of their connection to the colonial and imperial agenda (p. 131). Ueda (2008) recognises the value of this scholarship that began to adopt a new focus on the production of a new national language and its ideological implications and believes that such scholarship did much to criticize the developmental view of genbun'itchi that Yamamoto presented (p. 131), but she nevertheless finds problems in their approach:

However, as valuable as this scholarship has been, it regrettably has its own teleological narrative: it focuses on the production of an ideologically-charged "national language" (kokugo), which forcefully excludes or assimilates otherwise heterogeneous languages. It posits the nation as a pre-existing entity, whose regulative idea is used to characterize the many linguistic reforms in early Meiji Japan. In large part this scholarly trend reflects the notion of "imagined communities" posited by Benedict Anderson's book of the same name; Anderson theorized the ideological formation of the nation state in which the production of "national language" plays a significant part. Recent scholarship has appropriated this theory, producing a teleological narrative that posits the "national language" of the imagined nation as the putative telos, often producing an inverted narrative that posits the nation as an entity that inspired the movement that created it. Such a paradigm, which can be seen in some more than in others, posits the nation as telos and hence as a pre-existing entity, and the urge to nationalize is deemed the primary cause of change; the formulaic discussions that seemingly trace the nation-building process often end up in a selffulfilling prophecy (pp. 131-132).

Ueda claims that modern kokugo scholars are inverting Anderson's concept of "imagined communities" by not theoretically arguing the construction of nation, but rather appropriating it as a pre-existing concept that necessarily gives birth to the idea of a single "national language". On the other hand, Joseph (2004) claims that Anderson's constructionist approach to nationalism is purchased at the price of an essentialist outlook on languages (p. 124). It seems then, we are confronted with two inverted narratives: if modern kokugo scholars discuss the concept of the national language based on an essentialist outlook on nation, Anderson's theory, on the other hand, supposedly discusses nations based on an essentialist outlook on languages. Joseph (2004) therefore proposes that nations and languages are in fact dialectically co-constructed and arise in tandem (p. 124). This idea, also taken up in Makoni and Pennycook (2007), is based mostly on Hobsbawm's (1990) approach that understands the national language itself as a discursive construction (Joseph, 2004, p. 120), however, Joseph is quick to distance himself from the possibility of delving too deep into a materialist or "Marxist" interpretation of language and nation. He quotes Michael Silverstein's critique of Anderson's blind spot concerning language determinism, and finally dismisses Silverstein as being close to vulgar-materialist reduction which asserts that the only "real" facts are the political processes and political economic conflict which underlie the discourse through which the national/standard language is battled into existence and that ideologies of language are merely a reflection of what is real and have no reality in themselves (p. 124). 
However, in my opinion, it is exactly this shying away from a materialist method that blocks any possibility of an actual theoretical breakthrough, since without the historical materialist perspective it is impossible to produce a theory, i.e. to produce an epistemological cut that separates it from its spontaneous ideological exteriority. Therefore, rather than shying away from it, we should, on the contrary, embrace it in all its orthodoxy, if we wish to construct a theory of linguistic ideologies in the context of the national framework. Through the century-long process of discrediting historical materialism ${ }^{13}$ within social theory, theory itself has been almost completely eradicated from the sphere of social sciences. Even authors who still attempt theoretical practice are usually full of caveats and excuses in order not to be labelled as Marxists. The result of discredited Marxism and its orthodox historical materialist approach is a heap of idealistic scholarship delving into sombre mysticism, identity discourses and discussions about "national characters" or conflicts between individual and society on one side, and the careful or "moderate" attempts at materialist approach to society on the other.

Tanaka Katsuhiko (1989), when he constructs his own theory of language ideologies, compares Marxism to the Neo-grammarians "scientific" naturalism, saying that the conviction that the human phenomena were independent of human consciousness and that they blindly came into existence according to some set formula or law was characteristic of much nineteenth-century thought, in particular Marxism (p. 168). However, to accuse Marxist theory of "blind scientific naturalism" is to disregard the basic idea of the method of dialectic materialism that explicitly argues against any kind of empiricist social science that desperately follows the natural science paradigm of "objectively describing the reality". Tanaka criticises the Marxist approach by quoting Engels' explanation of dialectics in the Anti-Dühring (Tanaka, 1989; Tanaka, 2004), however, Lukács (1922), on the other hand, has pointed out that no matter how we regard some of Engels' arguments in the Anti-Dühring, whether we grant them classical status or whether we criticise them, deem them to be incomplete or even flawed, we must still agree that the real nature of dialectical method is nowhere treated in them (section 1, para. 4).

By saying we should return to the orthodox method of historical materialism in order to construct a theory of language ideology, therefore, does not imply following blindly everything Marx or Engels might or might not have stated, but rather means accepting its method. Lukács (1922) claimed that failing to understand what dialectical method is, if its true meaning is obscured, dialectics must inevitably begin to look like a superfluous additive, a mere ornament of Marxist "sociology" or "economics". Even worse, it will appear as an obstacle to the "sober", "impartial" study of the "facts", as an empty construct in whose name Marxism does violence to the facts (section 1, para. 7). However, it must be stated clearly in response to those who accuse the theorists of forcing the theory upon the "facts" instead of first "objectively" examining these

\footnotetext{
${ }^{13}$ Usually simply under the label of Marxism.
} 
"facts", that in theory there is no such thing as "objective" facts or as Lukács (1922) has put it:

The blinkered empiricist will of course deny that facts can only become facts within the framework of a system - which will vary with the knowledge desired. He believes that every piece of data from economic life, every statistic, every raw event already constitutes an important fact. In so doing he forgets that however simple an enumeration of "facts" may be, however lacking in commentary, it already implies an "interpretation". Already at this stage the facts have been comprehended by a theory, a method; they have been wrenched from their living context and fitted into a theory (section 2, para. 2).

In order to progress from these "facts" to facts in the true meaning of the word it is necessary to perceive their historical conditioning as such and to abandon the point of view that would see them as immediately given: they must themselves be subjected to a historical and dialectical examination (Lukács, section 2, para. 10). If we understand that historical character of facts, then we must also become aware that by addition they are also precisely in their objective structure the products of a definite historical epoch, namely capitalism (Lukács, section 2, para. 9).

It is thus necessary to observe these "facts" within their historical context, in other words, to theorise about nation and language within the structure of the capitalist world-system through the dialectical method in order to be able to grasp the problem in its totality. This dialectical conception of totality is the only method capable of understanding and reproducing reality. It is important to note, as Lukács (1922) does, that in the case of social reality these contradictions are not a sign of the imperfect understanding of society; on the contrary, they belong to the nature of reality itself and to the nature of capitalism (Section 3, para. 2) When the totality is known they will not be transcended and cease to be contradictions. Quite the reverse, they will be seen to be necessary contradictions arising out of the antagonisms of this system of production. When theory (as the knowledge of the whole) opens up the way to resolving these contradictions it does so by revealing the real tendencies of social evolution (Section 3, para. 2).

On the surface, therefore, we had many contradicting language ideologies and arguments for the reform in the Meiji period which seemed in great contrast with each other. In 1880s Japan we had, on the one hand, the popularity of kanbun kundokutai in newspapers, textbooks, fictional works, and compositions (Ueda, 2008, p. 139). Yet on the other hand the arguments for language reforms - whether it was the Roman alphabet, kana scripts, or genbun'itchi - almost always targeted kanji, kanji compounds, and kanbun for criticism. As a result, it appears that the forces supporting kanbun kundokutai and language reforms were not only separate, but worked against each other (Ueda, 2008, p. 139). The privileging of sound in Western linguistic theories, moreover, further reinforced the binary oppositions (spoken/written, phonetic scripts/ideographs) that supported such seemingly opposing forces (Ueda, 2008, p. 139). 
However, if we place these opposing forces in a theoretical perspective, it becomes clear that while they were antagonistic on their manifest level, they were not in fact antagonistic in their ideological conditions of existence. In other words, these views were not based on theoretical premises since they were all merely ideological adaptations to the new social reality, engaging in ideological struggle for the hegemonic interpretation of this reality. In fact all these opposing views actually sought to sever the past from the present, to accommodate the nationalistic and linguistic ideologies to the new actual conditions of Meiji Japan. One of Ueda's (2008) criticisms pointed towards modern kokugo scholars is that they focus on the period of Ueda Kazutoshi and post the Sino-Japanese war era from the mid-1890s which highlights what many call language nationalism (p. 132). Ueda (2008) goes on to discuss the discursive conditions by which kokugo became possible in the period preceding Ueda-led reforms and she shows how the emergence of kokugo in fact negotiated with the proliferation of kanbun kundokutai style of writing in the 1880s. She tries to show that this style of kanbun or classical Chinese that employed Japanese word order and suffixes and gained wide popularity in the Meiji period goes against the claims of those who argue that new nationalistic ideas and the urge of deAsianization (Datsu-a) were the basis of kokugo ideology. Ueda (2008) might be right in her criticism that explaining the emergence of kokugo simply with the rise of nationalist ideology is too simplistic and necessarily insufficient. However, she does not provide an alternative theoretical approach that would enable us to situate the question of language ideologies within the broader socio-economic context of the liberal bourgeois society of Meiji Japan.

Therefore, before embarking onto various explanations of how language ideologies emerged within nation-states, or arguing the birth of national consciousness based on supposedly natural linguistic communities, we should first take a look at how the emergence of the capitalist system in Europe has led to the establishment of the nationally structured societies of abstract individuals free from any status-related or other ties, but at the same time also on the path of alienation from their means of production. In order to understand this complex interconnection of linguistic and national ideologies in their totality, we have to understand them dialectically in their proper historical context by following the path to abstraction.

To put it in a necessarily insufficient schematic way, we can say that a major consequence of the capitalist mode of production was the process of alienation of the means of production from the producers, thus giving birth to new social classes of capitalists and proletarians, followed by the disintegration of feudal social ties and leading to a completely new form of social organisation of community, called nation. The specificity of this new type of social organisation was that it stripped its members of all family, status or any other kind of group-related identity ties and has embraced them in their complete abstraction, as abstract individuals to whom it now provided the only means of identity - national identity. In order to construct this imagined community another type of alienation had to take place: with the establishment of abstract standard national languages people finally became alienated from their 
language as well. The nation-state, by means of the school system as its ideological state apparatus, took it upon itself to teach its subjects the "proper" language. This is ideology in the true sense of the concept, while all the opposing discussions as to what this "proper" language actually is, provide just that necessary image of apparently "ideology-free" plurality of opinion on one hand, and reassurance in the seemingly "ideology-free" absolute nature of the national language on the other, and were thus of course not limited to Meiji Japan, but continue to be published ceaselessly in numerous academic monographs, papers, popular books and newspapers almost daily, whether it is in Japan or anywhere else in the world.

\section{References}

Burns, S. L. (2003). Before the nation: kokugaku and the imagining of community in early modern Japan. Durham, NC: Duke University Press.

Culiberg, L. (2007). Japonska med nacionalnim mitom in mitološko nacijo. Ljubljana, Slovenia: Založba /*cf.

Gottlieb, N. (1995). Kanji politics: language policy and Japanese script. London, New York: Kegan Paul International.

Gottlieb, N. (2005). Language and society in Japan. Cambridge, UK: Cambridge University Press.

Haga, Y. (1968). Kokugo to wa nanizo ya?. Meiji bungaku zenshū 44, 226-235. Tokyo, Japan: Chikuma Shobō.

Hitrec, H. (2010, October 28). Prijava HKV-a protiv odgovornih osoba u Ministarstvu kulture RH zbog sufinanciranja knjige "Jezik i nacionalizam”. In Portal Hrvatskoga kulturnog vijeća. Retrieved March 7, 2011, from http://hakave.org/index.php?option=com_content\&view=article\&id=7062:prijava-hkv-aprotiv-odgovornih-osoba-u-ministarstvu-kulture-rh-zbog-sufinanciranja-knjige-qjezik-inacionalizamq\&catid=17:hkv-priop

Hobsbawm, E. (1990). Nations and nationalism since 1780: programmes, myth, reality. Cambridge, UK: Cambridge University Press.

Joseph, J. E. (2004). Language and identity: national, ethnic, religious. Palgrave Macmillan.

Kamei, T., Ōtō, T., \& Yamada, T. (Eds.). (2006). Nihongo no rekishi 1: Minzoku no kotoba no tanjō. Tokyo, Japan: Heibonsha.

Karatani, K. (1995). Nationalism and écriture. Surfaces, V(201). Retrieved from http://www.pum.umontreal.ca/revues/surfaces/vol5/karatani.pdf

Kindaichi, H. (1988). Nippongo. Tokyo, Japan: Iwanami shoten.

Kordić, S. (2010). Jezik i nacionalizam [Language and Nationalism]. Zagreb, Croatia: Durieux.

Lee, Y. (1996). “Kokugo” to iu shisō: kindai nihon no gengo ninshiki. Tokyo, Japan: Iwanami shoten.

Lukács, G. (1919). What is orthodox Marxism?. In Marxists internet archive. Retrieved February 28, 2011, from http://www.marxists.org/archive/lukacs/works/history/orthodox.htm

Makoni, S., \& Pennycook, A. (Eds.). (2007). Disinventing and reconstituting languages. Clevedon, UK: Multilingual Matters Ltd.

Močnik, R. (1999). 3 teorije: ideologija, nacija, institucija. Ljubljana, Slovenia: Založba /*cf. 
Program Hrvatskoga kulturnog vijeća. (2006). In Portal Hrvatskoga kulturnog vijeća. Retrieved March 7, 2011, from http://hakave.org/index.php?option=com content \&view=article \&id=24\&Itemid=129

Tanaka, H. (1994). Modern Japan and Western Democracy: The Conflict between Liberalism and Nationalism. Hitotsubashi journal of social studies, 26(2), 55-61. Retrieved from http://hdl.handle.net/10086/8375.

Tanaka, K. (1989). The ideology of national and state language. Hitotsubashi journal of social studies, 21(1), 167-174. Retrieved from http://hdl.handle.net/10086/8416.

Tanaka, K. (2004). Kotoba to wa nani ka?: Gengogaku toiu bōken. Tokyo, Japan: Chikuma Shobō.

Ueda, A. (2008). Sound, scripts, and styles: Kanbun kundokutai and the national language reforms of 1880s Japan. Review of Japanese culture and society, 20, 131-154. Retrieved February 27, 2011, from http://www.princeton.edu/ piirs/projects/Ueda paper Nov09.pdf

Ueda, K. (1968). Kokugo to kokka to (1894). Meiji bungaku zenshū 44, 107-113. Tokyo, Japan: Chikuma Shobō.

Yasuda, T. (2006). “Kokugo" no kindaishi: teikoku nihon to kokugo gakusha tachi. Tokyo, Japan: Chūōkōron-shinsha. 
